\title{
EFFECT OF LASER IRRADIATION WITH DIFFE- RENT WAVELENGTH ON THE PROLIFERATION ACTIVITY OF HUMAN PULP FIBROBLAST CELLS, DEPENDING ON IRRADIATION PARAME- TERS AND HARD TISSUE THICKNESS
}

\author{
Sl. Dimitrov, V. Dogandzhiyska, N. Ishkitiev* \\ Department of Operative dentistry and Endodontics, Faculty of Dental Medicin- \\ Sofia, Medical University, Sofia \\ *Department of Biochemistry, Faculty of Medicine, Medical University, Sofia
}

\section{SUMMARY}

Several studies demonstrate, that low level laser therapy /LLLT/ improve the prognosis on direct and indirect pulp capping $/ 6,9,10,11,12,13,14 /$. Biostimulatory effect of laser irradiation represents a set of structural, biochemical and functional changes in living microorganisms $/ 6 /$. The positive effect is due to unspecific stimulatory action of laser beam - increase of colagen production, enzyme activity, micro- and lymph-circulation, fibroblast proliferation, decrease of local hypoxia, antiinflammatory effect and pain reduction $/ 3,4,6,8 /$.

Especially strong stimulatory effect is determined by irradiation with monochromatic red and infrared light with $630-905 \mathrm{~nm}$ wavelength. The low level laser irradiation from red and near infrared light spectrum correspond exactly to relevant characteristic energy and absorbtion level in the respiratory chain. It acts directly on stimulating components of the so-called antenna pigments of the respiratory chain and manifest as an immediate effect cell vitalization by ATP mitochondrial production increase $/ 3 /$.

Biostimulatory effect of laser irradiation is determined by the magnitude of the absorbed light energy. Energy depth of penetration depends on many factors - wave length, optical and temperature characteristics, power, energy values, exposure time, wave shape, and optical characteristics of tissue- absorbtion and scattering coefficient $/ 1,2,7,16 /$. Each tissue because of their structural and biochemical diversity will have individual translucence for laser irradiation with different wavelength $/ 2 /$.Greater oversight is typical of beam from red spectral area, and minimal such- of beam from blue spectral area /6/. As much translucenter tissue is, as minimal absorbtion and weaker biological effect of laser irradiation is. The cement is most transparent dental hard tissue, the second is dentin. Oversight of light energy through dentin is $0,2-0,8 \%$, and through enamel is $0,5-1,5 \% / 6 /$.

Key words: laser irradiation, pulp fibroblast cells, proliferation, biostimulatory effect

\section{MATERIALS AND METHODS}

The aim of this study was to investigate and compare the effect of two different lasers, with wavelength $630-650 \mathrm{~nm}$ and $10,89-0,91 \mu \mathrm{m}$, on the proliferation activity of human pulp fibroblast cells, according to irradiation parameters and hard tissue thickness.

There were isolated mesenchymal pulp cells from wisdom-tooth of 28-years old woman. Immediately after tooth extraction pulp chamber was opened with sterile burs and pulp tissue was extracted with sterile barbed broach. The pulp tissue was treated with Colagenasa V or Tripsin. Primary cell cultures were initiated from the suspension and cultivated in Dulbecco's modification of Eagle's medium / DMEM/, with $10 \%$ fetal calf serum /FCS/ by constant conditions $-37^{\circ} \mathrm{C}, 5 \% \mathrm{CO} 2 /$ Fig. 1./. When $80 \%$ confluence was reached, the primary cell cultures were tripsinised, screened in secondary cultures and grown in the same environment, daily replaced. For the purpose of this study were used cells from the fifth passage, placed in $3 \mathrm{ml}$ medium /fig. 2/.

Fig. 1. Mesenchyme pulp cells, cultivated in Dulbecco's modification of Eagle's medium /DMEM/, with $10 \%$ fetal calf serum/FCS/ and $1 \%$ Penicillin/Streptomicine

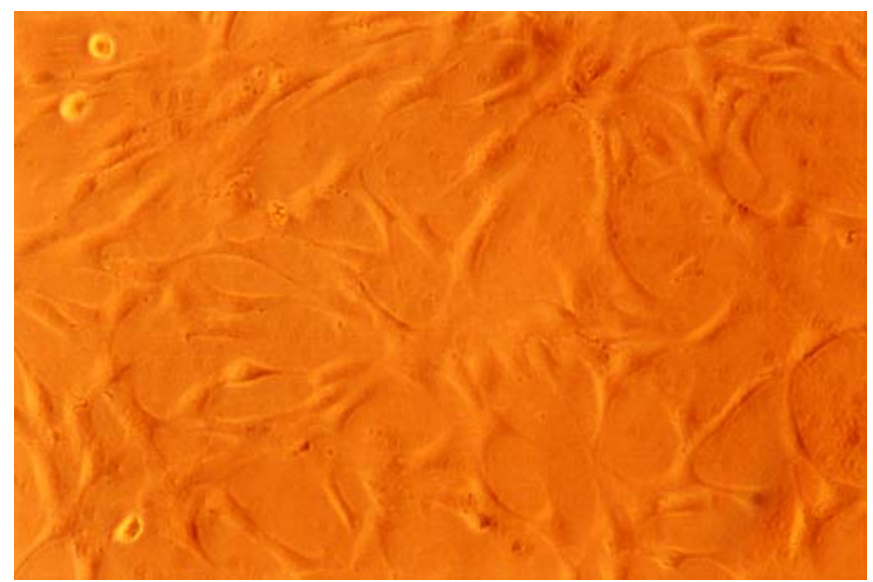


The cells were divided into two groups /Fig. 2./. Group 1 was irradiated with laser beam with $630-650 \mathrm{~nm}$ wavelength, and group 2-with laser beam with 10,89-0,91 $\mu \mathrm{m}$ wavelength.

Each group was divided into five subgroups: a/ direct irradiation

$\mathrm{b} /$ irradiation through 1 мм dentin section

c/ irradiation through 1,5 mM dentin section

$\mathrm{d}$ / irradiation through $3 \mathrm{~mm}$ enamel-dentin section

e/ control group-without laser irradiation

Fig. 2. Mesenchyme pulp cells, cultivated in Dulbecco's modification of Eagle's medium /DMEM/, with 10\% fetal calf serum/FCS/ and 1\% Penicillin/Streptomicine, and divided into two groups
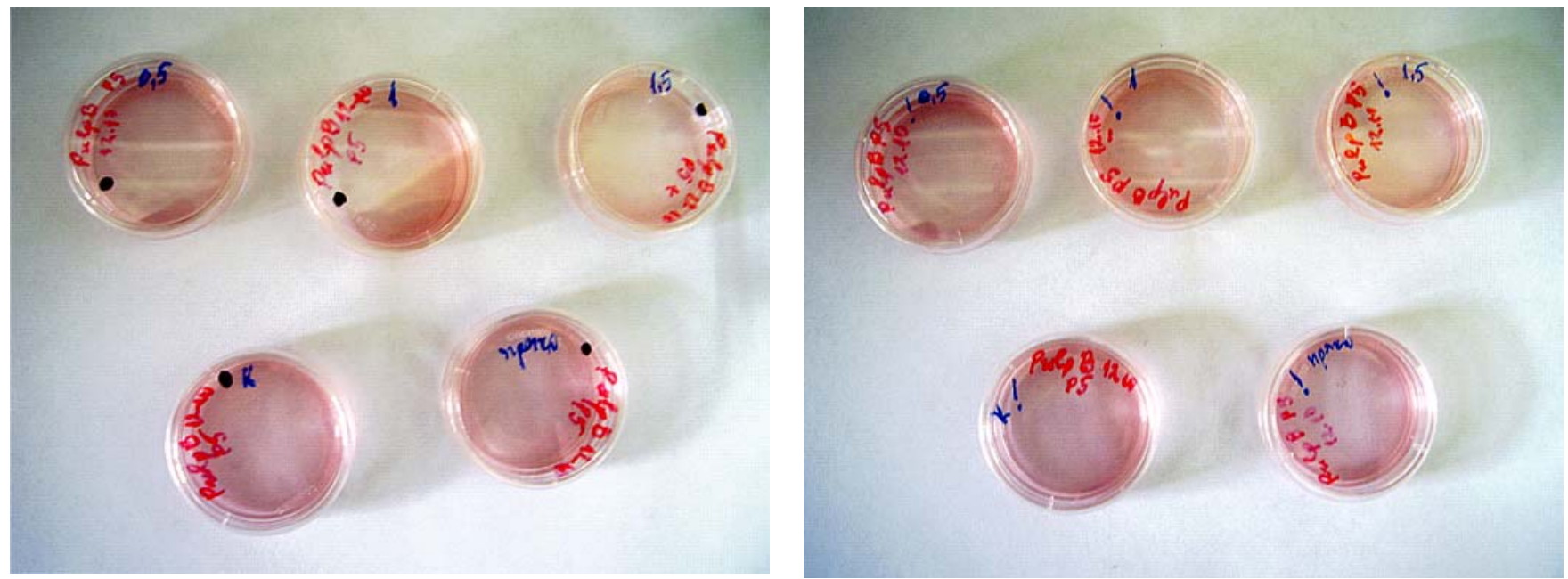

Each group was irradiated three consecutive days with definite parameters and gradual increasing time of irradiation /Tab. 1./.

Table 1. Parameters of laser irradiation

\begin{tabular}{|l|c|c|c|c|c|c|}
\hline \multirow{2}{*}{} & \multicolumn{3}{|c|}{ Time } & \multicolumn{3}{c|}{ Parameters } \\
\cline { 2 - 7 } & I day & II day & III day & I day & II day & III day \\
\hline GROUP 1 & $1 \mathrm{~min}$ & $1,5 \mathrm{~min}$ & $2 \mathrm{~min}$ & $25 \mathrm{~mW}$ & $25 \mathrm{~mW}$ & $25 \mathrm{~mW}$ \\
\hline GROUP2 & $30 \mathrm{sec}$ & $30 \mathrm{sec}$ & $30 \mathrm{sec}$ & $4,3 \mathrm{~W} 10 \mathrm{~Hz}$ & $4,3 \mathrm{~W} 10 \mathrm{~Hz}$ & $4,3 \mathrm{~W} 10 \mathrm{~Hz}$ \\
\hline
\end{tabular}

The laser tip was directed always perpendicular to irradiated surface, in order to maximize performance of action /Fig. 3., Fig. 4. /.
Fig. 3. Experimental production

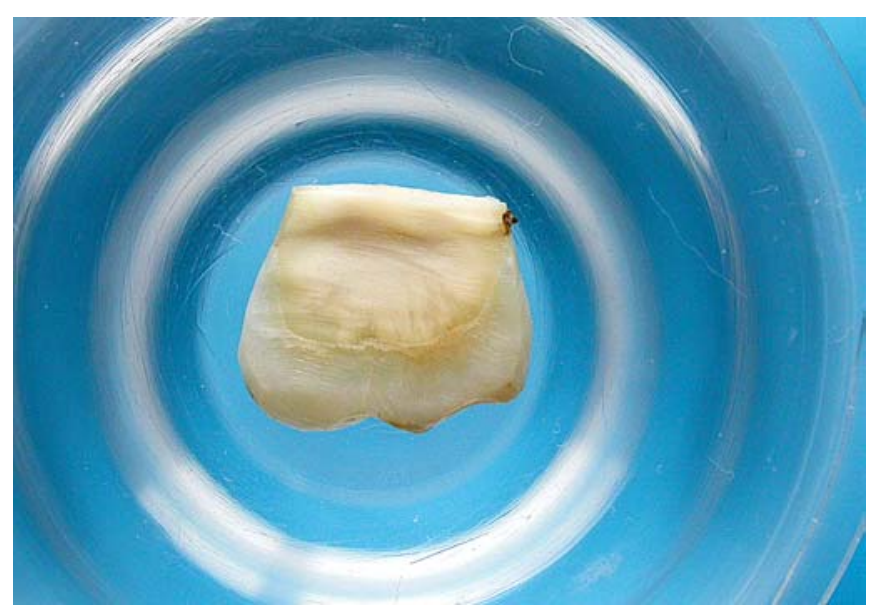


Fig. 4. Laser irradiation through tooth sections with different thickness

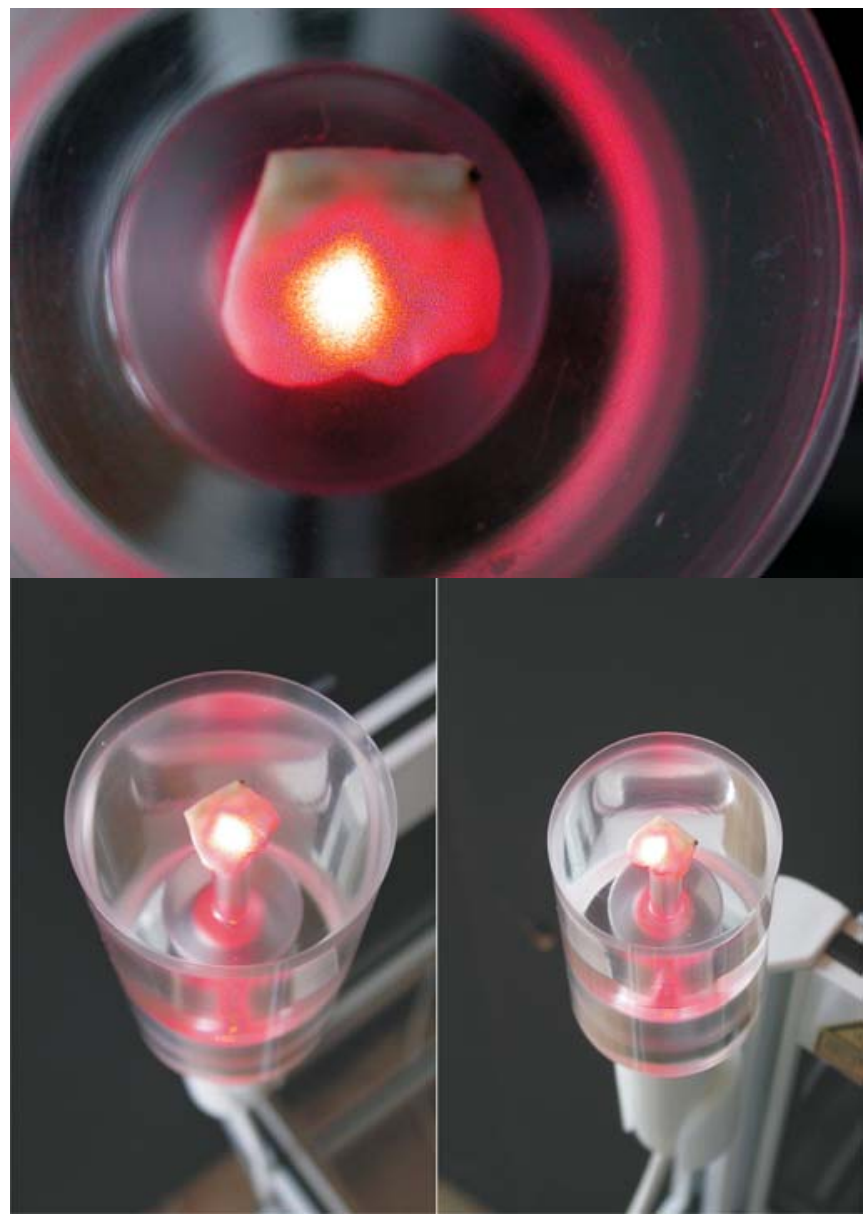

The cell proliferation was established by means of the method of measuring the inclusion of $3 \mathrm{H}$-timidin in the newly synthesised DNA of the proliferating cells. The cells were treated with a set of mitogenic factors for a period of $24-48 \mathrm{~h}$. During the last four hours of the treatment radioactively- marked timidin - $1 \mathrm{jCi} 3 \mathrm{H}$-timidin - was added to the cell cultures. By means of trichloroacetic acid the cells were fixated and cleansed from the radioactive timidin unabsorbed by the DNA and then lysined in $1 \mathrm{~N}$ $\mathrm{NaOH}+1 \% \mathrm{SDS}$. The radioactivity of each sample was report on Beckman- scintillation counter. Cell proliferation was define with measurement of included $3 \mathrm{H}$-thymidin in the new synthesized DNA in the divided cells . The percentage of inclusion of $3 \mathrm{H}$-thymidin in the molecules in the new synthesized DNA from proliferated cells was determinate tomg of protein toward control group /untreated cells/ The number of reported radioactive decays is in a direct ratio to proliferation activity of pulp fibroblast cells /Fig. 5./

\section{RESULTS AND DISCUSSION}

In group 1 upon irradiation with parameters listed in table /Tab. 1/ was determined inhibition of cell proliferation compared with control group. It was most pronounced upon laser irradiation through $1 \mathrm{~mm}$ dentin section and $3 \mathrm{~mm}$ enamel-dentin section. Upon direct irradiation was also observed, albeit very slightly delayed proliferation. Many authors $/ 4,5 /$ were investigated the biological effect of direct irradiation with Helium-neon laser /wavelength $632,8 \mathrm{~nm}$, power density $0,1-50 \mathrm{~mW} / \mathrm{sm}^{2} /$.They were determined $2,5-$ 7,5 times higher increase of cell proliferation, according to exposure time $/ 30 \mathrm{sec} .-30 \mathrm{~min} . /$ and number of irradiations. They, however, established inhibitory effect on the proliferation by irradiation with power density $108 \mathrm{~mW} / \mathrm{sm}^{2}$ and exposure time $5 \mathrm{~min}$, also in reducing the emission of Pt.

Fig. 5. Correlation between laser irradiation parameters and $3 \mathrm{H}$-thymidin, included in the new synthesized DNA from proliferated cells

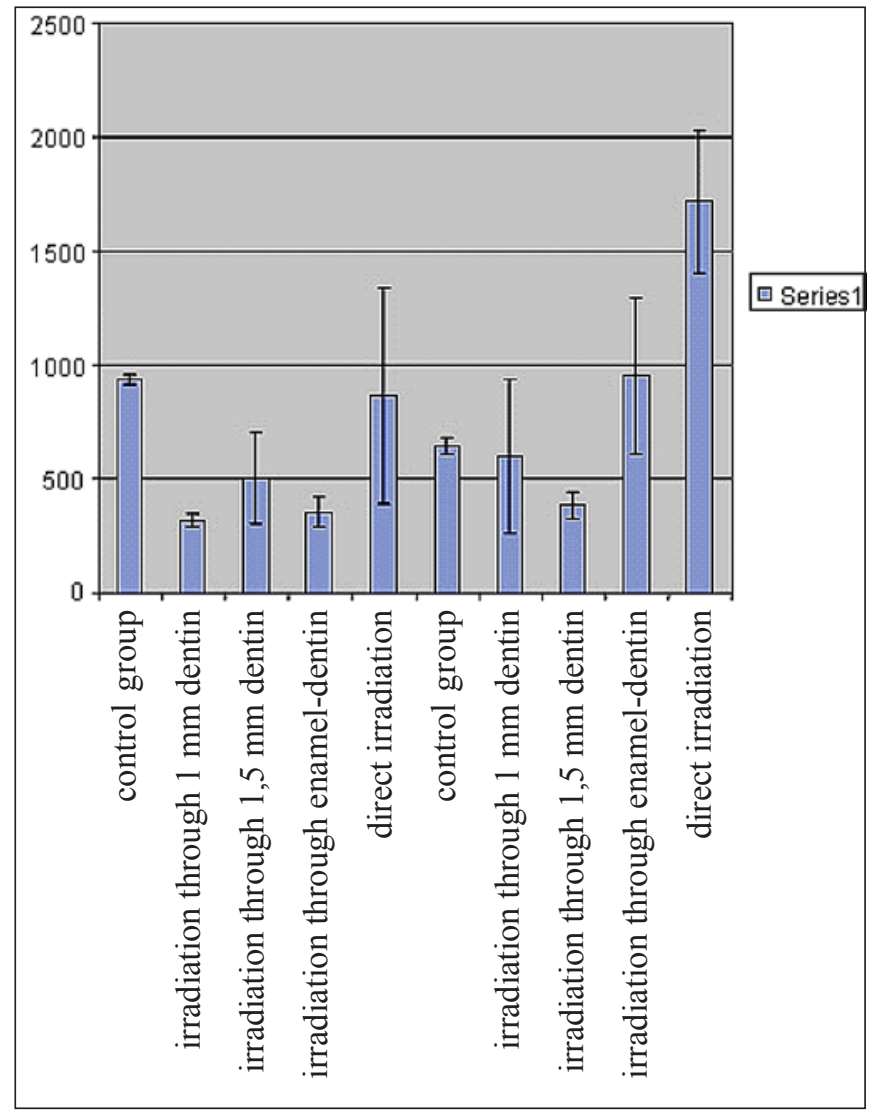

Reasons for the negative results obtained in the present study may be: unsuitable parameters/ power density, time, number of irradiations/; increasing of power density and irradiation dispersing through dental hard tissue sections; characteristics of mesenchymal pulp cells, special feature of there cultivation and experimental conditions. This 
is probably the reason, that the proliferation in two control groups is $100 \%$ different - fact, that at this stage of our investigations can't be explained.

In group 2 upon direct laser irradiation was determined 2,5 times higher increase of proliferation activity, compared with control group. Upon irradiation through enamel-dentin sections was determined near $100 \%$ increase in proliferation activity, low inhibition upon irradiation through 1,5 Mm dentin section and the same as in the control group upon irradiation through 1 мm dentin section. Similar results were received by direct irradiation of fibroblasts with infrared laser with similar parameters of other authors $/ 5,13$, 15/. The weaker effect of influence through dental hard tissue sections can be explained by reasons already mentioned.

\section{CONCLUSION}

In the present study was carried out for the first time research to stimulation of proliferation activity of mesenchymal pulp cells with two type laser irradiation through different sections of dental hard tissue. There was determined marked stimulatory effect on proliferation activity of human pulp fibroblast cells upon direct irradiation with infrared laser and lower upon irradiation through different sections of dental hard tissue. Upon irradiation with Helium-neon laser was determined inhibitory effect on the proliferation activity. It's possible that a part of the mesenchymal pulp cells were differentiated into another cells. That will be explained with Western blot analysis in the second part of our investigation.

Forthcoming investigations will explain the vitality of isolated mesenchymal pulp cells, their identification and differentiation possibility, the permeability of laser beam through different sections of dentin and enamel, power density of passed light, time and number of exposures in order to achieve the optimal effect on proliferation.

\section{REFERENCES}

1. Атанасова, Е., и др.. Прозрачност на тъканите на устната кухина за лазерното льчение от видимата спектрална област.Стоматология, LXXIII, 2, 1986, 29-34

2. Атанасова, Е., и др.. Пролиферативна активност на нормални и ракови клетки, обльчени с полупроводников GaAlAs диоден лазер.Стоматология, LXXII, 5, 1990, 10-16

3. Вилден, Л., Ю. Картайн, Р. Картайн. Механизъм на въздействие на лъчението на low-level лазерите върху клетката. Дентал алманах, 2004, 10, 119 124

4. Прохончуков, А. и др.. Лазерная физиотерапия стоматологических заболеваний. Стомат., М., 74, 6, 1995, 23-24

5. Прохончуков, А., Н. Жижина. Лазерьи в стоматологии. М. Медицина, 1986

6. Ттојачанец, 3.. Биостимулирачки Ласери во Стоматологијата. 1995
7. Kimura, Y., et al.. Effect of Er: Cr: YSGG laser irradiation on canine mandibular bone. J Periodontology, 72, 9, 2001, 1178-1182

8. Kreisler, M., et al..Effect of diode laser irradiation on the attachment rate of periodontal ligament cells: an in vitro study. J periodontology, 72, 10, 2001, 1312-1317

9. Moritz, A. , et al.. The $\mathrm{CO}_{2}$-laser as an aid in direct pulp capping. Journal of Endodontics, 24, 4, 1998, 248-251

10. Moritz A, U. Schoop, K. Goharkhay, W. Sperr. Advantages of a pulsed $\mathrm{CO} 2$ laser in direct pulp capping: a long-term in vivo study.Lasers Surg Med., 22, 5, 1998, 288-93

11. Olivi G., M. D. Genovese, P. Maturo, R. Docimo. Pulp capping: advantages of using laser technology. Eur J Paediatr Dent, 8, 2, 2007, 89-95

12. Olsson H., K. Petersson, M. Rohlin. Formation of a hard tissue barrier after pulp capping in humans. A systematic
review.International endodontic journal, 39, 2006, 429-442

13. Paschould, Y., J. Holz. Effet du soft-laser sur la neoformation d'un pont dentinaire apres coiffage pulpaire direct de dents humaines a lhydroxide de calcium"Rev. mens. Suisse odonto-stomatol., .98, 4, 1988, 345-356

14. Santucci, P. J. Dycal versus Nd:YAG laser and Vitrebond for direct pulp capping in permanent teeth. J Clin Laser Med Surg., 17, 2, 1999, 69-75

15. Suzuki, M. et al.. Effects of an experimentally developed adhesive resin system and $\mathrm{CO}_{2}$ laser irradiation on direct pulp capping. Operative dentistry, 30, 6, 2005, 702-718

16. Theodoro, L. H., et al.. Effect of Er:YAG and diode laser irradiation on the root surface : morphological and thermal analysis. J Periodontology, 74, 6, 2003, 838-843

\author{
Address for correspondence: \\ Violeta Dogandzhiyska \\ Department of Operative dentistry and Endodontics, \\ Faculty of Dental Medicine, \\ 1, Georgi Sofiiski str., 1431 Sofia, Bulgaria \\ E-mail: Dogandzhiyska@gmail.com
}

